\title{
What is the best medical approach in octogenarian patients with coronary artery disease? A 6-year experience
}

\section{Kardiyak yetmezliği olan ileri yaş hastalarda en iyi tedavi yaklaşımı nedir? 6 yıllık deneyim}

\author{
Hasan Hakan ATALAY* D
}

\author{
Mersin Ortadogu Hospital, Cardiovascular Surgery Clinic, Mersin/TURKEY
}

\begin{abstract}
Aim: Best popular perception that coronary artery bypass grefting in octogenarians carries high risk related primarily to advanced age. Nevertheless, the effects of CABG, percutaneous coronary intervention , and medical treatment were not assessed on life adequately.
\end{abstract}

Material and Methods: In the present study, survival duration of 375 octogenarian patients who underwent coronary angiography (CAG) in our clinic was evaluated retrospectively.

Results: Patients were assigned and compare to seven groups as follows: group 1, patients with normal CAG results; group 2, patients with diffuse coronary narrowness who received medical treatment, group 3, patients who underwent $\mathrm{PCl}$, group 4 was the subgroup of patients from group 3 who underwent $\mathrm{PCl}$ in the left anterior descending artery only or in combination with their coronary arteries; group 5, patients in critical condition who were unavailable for any intervention because of cardiac function, group 6, patients who underwent CABG; and group 7, patients who declined the recommended CABG and PCI. For each group, the first-year survival rates were respectively: $100 \%, 95 \%, 91.2 \%, 91.8 \%$, $76.1 \%, 93.0 \%, 90.82 \%$. After 6 years, the survival rates were respectively: $76.1 \%, 80.0 \%, 72.5 \%, 71.42 \%, 52.3 \%, 90.2 \%$, $76.14 \%$. Rates of patients living by years a significant correlation was revealed between group 6 and group 2 and group 3 $(p=0.001, p=0.004)$. Group 3 was found to have a significant correlation with Group 4 and Group $7(p=.000)$. Group 7 was significantly correlated with groups $3(p=0.000), 4(p=0.000)$, and $2(p=0.007)$.

Conclusion: Especially in octogenarians who had shortness of the expected survival, the surgical advantage of visual anastomotic replacement, and complete vascularization were successed more than $\mathrm{PCl}$.

Keywords: cardiac disease; Coronary artery bypass grefting; octagenarian 


\section{öz}

Amaç: Genel algı 80 yaş ve üzeri hastalarda, koroner bypass cerrahi $(K B C)$ riskinin daha yüksek olduğu yönündedir. Bununla birlikte, KBC, perkütan koroner arter girişim ve tıbbi tedavinin ileri yaş hasta grubunda yaşam kalitesi üzerine etkileri kapsamlı bir şekilde değerlendirilmemiştir.

Gereç ve Yöntemler: Çalışmamızda koroner anjiyografi yapılan 80 yaş ve üzeri 375 hastanın sağ-kalım süresi retrospektif olarak değerlendirildi. Sınırlı sağ-kalım üzerine bir tahmin modeli oluşturuldu.

Bulgular: KAG verilerine göre, hastalar yedi grupta değerlendirildi: Grup 1, sonuçları normal olan hastalar; grup 2, lezyonlar için medikal tedavi alan hastalar; grup 3, PCl yapılan hastalar; grup 4, yalnızca sol ön inen arteri (LAD) veya koroner arterleriyle kombine olan hastalar; grup 5, herhangi bir müdahale için uygun bulunmayan kritik durumdaki hastalar; grup 6, KBC geçiren hastalar; grup 7, önerilen girişimleri reddeden hastalardır. İlk yıl sağ-kalım oranının en düşük Grup 5 'de ( \% 76.1) olduğu tespit edilmiştir. 6 yıl sonra sağ-kalım oranının en yüksek grup 6 da olduğu görülmüştür (\% 90.2). Yıllara göre yaşayan hasta oranlarına bakıldığında Grup 6 ile grup 2 ve grup 3 arasında $(p=0.001, p=0.004)$. Grup 3 ile grup 4 ve grup 7 arasında $(p=0.000)$ ve grup 7 ile grup $2(p=0.007)$ arasında ile anlamlı bir korelasyon bulundu.

Sonuç: Bu çalışmada özellikle beklenen yaşam süresi kısa olan ileri yaş hastalarda, görsel anastomotik replasman ve tam vaskülarizasyonun cerrahi avantajı, PCl'den daha başarılı olmuştur.

Anahtar kelimeler: kardiyak cerrahi; koroner bypass; ileri yaş hastalar

\section{Introduction}

Many studies have demonstrated that $25 \%$ of individuals aged above 80 years' experience severe complications owing to cardiovascular disease.[1] The average expected survival duration for normal individuals. Octogenarians in the United States was calculated to be an 8.1 years. [3,4] The shortness of the expected survival and estimates for the best treatment options are uncertain for those Octogenarians who experience coronary heart disease. Thus, many internists are reluctant to refer Octogenarian patient for coronary artery bypass grefting (CABG) because of the significant independent predictor of post-operative mortality.

An increased octogenarian's population will gradually change physicians' recommendations regarding medication, percutaneous coronary intervention $(\mathrm{PCl})$, and the surgery for coronary heart disease, as well as the success rates of these treatments. Thus compared with past interventions, more aggressive approaches are currently required. Additionally, studies performed in advanced-aged patient groups have generally excluded those who were clinically uncontrolled regardless of the surgical decision, and no evaluation was conducted on their survival duration; data were obtained only from treated patient groups.[3-6] The objective of the present retrospective single center study was to evaluate the treatment results with respect to short- (1- year) and long- term (6-year) survival rates in octogenarians who were administered available treatment options for suspected coronary artery disease.

\section{Material and Methods}

The present retrospective study included 375 octogenarian patients who underwent coronary angiography between June 2010 and June 2016.

Patients who had severe valve disease and required several types of emergency interventions were excluded from the study. The required data for patients who could not be examined were obtained by telephone from the patients or their relatives. The survival durations of the patients were determined. Based on the records of the coronary angiography findings (CAG), were assigned to seven groups as follows: group 1 , patients with normal CAG results $(n=42)$; group 2, patients with coronary narrowness who received medical treatment for lesions $<50-75 \%(n=40)$; group 3, patients who underwent $\mathrm{PCl}(\mathrm{n}=91)$; group 4, patients from group 3 who underwent $\mathrm{PCl}$ in their left anterior descending (LAD) artery only or in combination with their arteries $(n=48)$; group 5, patients in critical condition who were unavailable for any intervention because of cardiac function, coronary disease's or co morbid conditions ( $n=21$ ); group 6, patients who underwent coronary bypass surgery $(n=72)$; and group 7 , patients who declined 
the recommended operative procedure $(n=109)$. Differences in survival times between 7 groups were assessed. Data were conducted with SPSS version 16.0.

For patients who underwent surgery, our coronary bypass strategy consisted of using blood cardioplegia and used cardiopulmonary bypass at $32-34^{\circ} \mathrm{C}$ hypothermia. However, the beating heart bypass technique was used for some clinical conditions such as severe chronic obstructive pulmonary disease (COPD), impaired general condition, renal failure, and porcelain aorta, etc. The $\mathrm{PCl}$ procedure varied depending on the equipment and techniques available at the time of each patient's treatment. Therefore, the preferred sent trademarks and their features were not considered in the analysis.. Informed consent was obtained from all patients. The ethics committee of our institution approved the study protocol and procedures were carried out in accordance with the 2013 Helsinki Declaration.

\section{Results}

The mean patient age was $80.47 \pm 1.79$ years for patients who underwent CABG (group 6) and 82.12 \pm 2.24 years for patients who underwent $\mathrm{PCl}$ (group 3). For each group, the total number of patients, numbers of male and female patients, total number of deaths, and cardiac deaths are presented in Table 1. The survival rates in years 1 and 6 are presented in Table 2. A greater proportion of bypass patients were female (group $6,55.55 \%$ female), compared with the proportion of females undergoing $\mathrm{PCl}$ (group 3,51.76\%). The 6- year death rates in the patient groups, excluding patients lost to follow-up, is presented in column of Table 1. 14.93\% of death reasons were not associated with heart disease and number of patients no available for follow-up were not affect the total deaths $(p=0.46)$ but cardiac deaths $(p=0.005)$ and follow-up patients $(p=0.004)$ were correlated, tightly. The death reasons and survival rates of the patients between years obtained from the clinical results were evaluated in Column of Table 1.

On average, 4, 18 coronary bypasses were performed per surgical procedure (minimum, 1; maximum, 7) with $48.61 \%$ of patients $(n=35)$ receiving four or more coronary bypasses. The left internal mammary artery (LIMA) used procedure was performed in $97.22 \%$ of bypass patients $(n=70)$. No patient underwent a bilateral LIMA used, and none had left main coronary artery disease. Ten patients (13.88\%) underwent the beating heart bypass technique. The mean hospitalization duration was 6.61 days (range, 3-37 days) for coronary bypass patients, 5.9 days (range, 4-8 days) for beating heart method only patients, and 5.39 days ( range, 3-18 days) for isolated coronary bypass only patients, respectively. An intra-aortic balloon procedure was used in any of the patients.

Rates of patients living by years a significant correlation was revealed between group 6 and group $2(p=0.001)$ and group $3(p=0.004)$. Group 7 was significantly correlated with groups $3(p=0.000), 4(p=0.000)$, and $2(p=0.007)$.

A total of $75 \mathrm{PCl}$ procedures were performed in a single coronary artery: 35, LAD; 1 , diagonal artery; 16, circumflex artery $(C X)$ and 24 , right coronary artery (RCA). In nine cases, stents were placed in two coronary arteries: 5 LAD and $C X$; and $4 \mathrm{LAD}$ and RCA. A balloon dilatation procedure was used in six cases: 4, LAD; 1, diagonal artery; and 1, CX. The hospital death rates following interventional and 0-30 day after in groups 3 $(\mathrm{PCl})$ and 6 (Surgery) are shown in Table 3.

\begin{tabular}{|c|c|c|c|c|c|c|c|}
\hline Groups & $M$ & $F$ & $\begin{array}{l}\text { One-year deaths, n } \\
\text { (survival rate, \%) }\end{array}$ & $\begin{array}{l}\text { Total deaths, } \mathrm{n} \\
\text { (Death rate, } \% \text { ) }\end{array}$ & $\begin{array}{c}\text { Cardiac deaths, } \\
\text { n (\%) }\end{array}$ & $* *$ & $* * *$ \\
\hline 1 & 19 & 23 & $0(100)$ & $8(80.9)$ & $1(2.3)$ & $\% 27.7$ & 8 \\
\hline 2 & 20 & 20 & $2(95)$ & $8(80)$ & $5(12.5)$ & $\% 26.6$ & 10 \\
\hline 3 & 44 & 47 & $8(91.2)$ & $25(72.5)$ & $10(10.9)$ & $\% 29.0$ & 5 \\
\hline 4 & 20 & 28 & $4(91.8)$ & $14(71.4)$ & $6(12.2)$ & $\% 29.7$ & 2 \\
\hline 5 & 13 & 8 & $5(76.1)$ & $10(52.3)$ & $7(33.3)$ & $\% 76.9$ & 8 \\
\hline 6 & 32 & 40 & $5(93.1)$ & $7(90.2)$ & $3(4.1)$ & \%10.6 & 6 \\
\hline 7 & 54 & 55 & $10(90.8)$ & $26(76.1)$ & $14(12.8)$ & $\% 28.2$ & 17 \\
\hline Total & 182 & 193 & 34 & 98 & $46(p=0.005)$ & $(p=0.004)$ & $56(p=0.46)$ \\
\hline \multicolumn{8}{|c|}{$\begin{array}{l}M \text {, male; } F \text {, female } \\
\text { ** death rate based on number of patients available for follow-up } \\
\text { ***number of patients not available for follow-up }\end{array}$} \\
\hline
\end{tabular}




\begin{tabular}{|c|c|c|c|c|c|c|c|}
\hline Year & Group1 & Group2 & Group3 & Group4 & Group 5 & Group 6 & Group 7 \\
\hline 1 & 97,61 & 90,00 & 93,40 & 91,83 & 100,00 & 100,00 & 94,49 \\
\hline 2 & 97,61 & 82,50 & 89,01 & 91,83 & 95,83 & 95,83 & 90,82 \\
\hline 3 & 95,23 & 82,50 & 84,61 & 85,71 & 76,19 & 94,44 & 88,99 \\
\hline 4 & 92,85 & 80,00 & 80,21 & 77,55 & 61,90 & 94,44 & 79,81 \\
\hline 5 & 92,85 & 80,00 & 75,82 & 75,51 & 52,38 & 94,44 & 77,06 \\
\hline 6 & 69,38 & 77,50 & 72,52 & 71,42 & 52,38 & 90,27 & 76,14 \\
\hline
\end{tabular}

\begin{tabular}{|c|c|c|c|c|}
\hline & $\begin{array}{l}\text { Deaths post-op before } \\
\text { discharge, } n(\%)\end{array}$ & $\begin{array}{l}\text { Deaths 0-30 days post discharge } \\
\qquad \mathrm{n} \text { (case) }\end{array}$ & $\begin{array}{l}\text { Total deaths } \\
\mathrm{n},(\%)\end{array}$ & Operation performed \\
\hline Group 3 & $7(\% 7.69)$ & 1 (RCA stent) & $8(\% 8.79)$ & $\begin{array}{l}\text { LAD stent, } 3 \text { cases } \\
\text { LAD \& CX stent, } 1 \text { case } \\
\text { CX stent, } 2 \text { cases } \\
\text { RCA stent, } 1 \text { case }\end{array}$ \\
\hline Group 6 & $2(\% 2.77)$ & 1 (3 coronary bypasses) & $3(\% 4.16)$ & 3 or 4 coronary bypasses \\
\hline
\end{tabular}

\section{Discussion}

The numbers of octogenarians have increased in recent years as the mean survival age of the population has exceeded 7 decades in developed countries.[2] It is known that this age group patients who had shortness of the expected survival exhibit different features compared with younger patients.[9]

For this purpose, 375 patients who successfully underwent elective coronary artery angiography between June 2010 and June 2016 were reinvestigated retrospectively. In the present study, these patients had received recommendations for medical treatment, Percutan Coronary Intervention (PCI) or coronary artery bypass grafting (CABG). Our study did not address whether patients regarded their comfort following any treatment and their return to normal physical and psychological functioning as being adequate. Our assessment of these patients was limited to solely survival duration following $\mathrm{PCl}$, cardiac bypass surgery, or medical treatment.

Our opinion that evaluating the success of selected treatment options based on survival duration is important in these patients, given their advanced age. Another critical consideration in the present study was the expected survival duration of octogenarian who declined recommended treatments (group 7) and those with normal coronary artery angiography results (group 1), which represent minimal and maximal indicator values $(p=0.06)$. No previous study has reported the evaluation of patient groups with respect to these criteria.

In cases involving three or more coronaries, diffuse and long segment of the coronaries, calcified aorta (porcelain aorta) and left major coronary artery disease, $\mathrm{PCl}$ as a treatment option presents both difficulty and severe complications in especially octogenarians. In total 91 octogenarian patients were treated using $\mathrm{PCl}$ under elective conditions (group 3). Of these six (6.59\%) underwent balloon procedures, and 85 $(93.41 \%)$ received stent placements. Mortality rates before discharge hospital patient were $7.69 \%$ and $2.77 \%$ among those receiving $\mathrm{PCl}$ (group 3) and CABG (group 6), respectively (table 3). Although, in the literature was found similar mortality rates for patients who underwent $\mathrm{PCl}$ and coronary artery bypass surgery; we performed surgery with better mortality rates that $\mathrm{PCl}$. The difference could be due to two reasons. First, that the patient which could not be operated because of body conditions and the second is the cardiologist experiences and willingness to help the patient who suffered trouble. Thus different octogenarian patient mortality frequencies following surgery and $\mathrm{PCl}$ were detected in octogenarians in a number of patient studies with large groups. $[2,10,12]$

In our study, compared with $\mathrm{PCl}$, coronary bypass surgery gave better survival rates at both time points (table 1). There may be several reasons for this difference: in CABG, selection of patients with better physical and psychological conditions for bypass surgery, complete revascularization[13], placement of a visually clearer graft to the safe distal coronary region, in addition to $\mathrm{PCl}$, application of $\mathrm{PCl}$ in a patient group with more problems, and placement of a stent at a critical region within the diseased area.[7] Compared with the male population, the female population has longer life expectancy and has been reported to more frequently undergo CABG.[14] Female patients have been reported to have a worse prognosis than male patients with regard to CABG.[15] In our study, three female and four male patients had died by end of this six year, in contrast to the ratios reported in the literature[8] And our long-term findings 
suggest that selection of the surgical option yields better results in elderly female patients (Table 1 ).

The process of age-associated tissue deterioration leads to a decrease in the overall health of aging populations. Although the biology of aging is not well understood, CVD is a common problem in the elderly.[16] Coronary artery bypass surgery essentially results in complete cardiac circulation in all coronaries, and the selection and availability of the preferred arterial and/or venous grafts depend on the patient as well as the structure and necessity of the graft. Saphen veins have demonstrated a worse potency rate than LIMA (Left Internal Mammary Artery) when long-term results were considered.[17] However, in selected elderly patients, saphen veins provided better results than LIMA's.[18] LIMA is preferred particularly for the left anterior descending artery in our clinic and could not be used in only two patients. Bilateral internal mammary arteries were not considered in calculating expected survival duration in octogenarians because long-term results (10-15 years) have not been successful.[19] Although the survival expectation was limited, the combination LIMA-LAD (left anterior descending artery) by-pass was more advantageous than bypass using saphen veins, because it decreased the crossclamp time, reduced the number of operations performed on the aorta, and provided the ability to adjust the diameter-flow in diseased and/or fine coronaries. Disease in venous grafts occurred after 5 years and disease occurring before 5 years could be treated by $\mathrm{PCl}$ and/or a simple operation.[20,21] No patient in our study required a second operation during follow-up. Except for IMA (Internal Mammary Artery), IMA-like inelastic muscular arteries such as radial, gastroepiploic and inferior epigastric arteries were not preferred in advanced-age patients, because of their predisposition to atherosclerosis. [22] Early-age obstruction has been found in these types of coronaries when atherosclerosis was evident. Thus, these arteries would be preferred after saphen vein procedures, particularly in advanced-aged patients.

The average post-operative hospitalization period of patients in whom a cardiopulmonary pump in CABG operation was used was 6.61 days, which was due to a delayed recovery period, the effects of surgery, the advanced overall age of organs, and the difficulty of personal care. The beating heart method was performed in 10 patients (13.38\%) in the present study. The objectives and results of this method have been well documented, and it is preferred in patients with severe COPD, impaired general condition, porcelain aorta, and advanced renal failure.[23] The post-operative hospitalization period for these patients was 0.51 days longer than that for patients who underwent coronary bypass with CPB (cardiopulmonary bypass) used. Although the beating heart method considerably shortened the post-operative hospitalization period, this method was no considered in some patients owing their advanced age and requirement of longer care.

We had none operated mortality but three patients died (4.16\%) developed mediasten infection; heart failure and sepsis; and heart failure, respectively, during post-operative days $0-30$. These results are comparable to the values reported in the literature.[4,14,24] Some researchers were also suggested that coronary bypass surgery provides more positive effects for survival than $\mathrm{PCl} .[25]$ In the coronary bypass patient group in our study, the survival rates after 1 and 6 years were $93.05 \%$ and $90.27 \%$, respectively, with bypass surgery yielding better survival than $\mathrm{PCl}$ during both periods. Similarly, 79.7\% [14], 66\% [25], and 84\% [4] long term survival rates have been reported in previous studies of octogenarians who underwent coronary bypass surgery.

In reported studies, the causes of mortality in advanced-aged patients who underwent bypass surgery were infrequently associated with heart disease (Table 1). However, their advanced age alone put most of our patients in our last decade of life, deaths without any clear cause, mortality unassociated with heart disease, and/or undiagnosed conditions made the interpretation of the follow-up record difficult.[3,4] The 56 (14.93\%) unreachable patients and 60 (16\%) patients who died without a known mortality cause indicate the importance of considering the benefits as well as the probability of success of surgery in the older population.

In companion to the study, group 7 (patients who declined recommended surgery) follow-up was caused the difference form the literatures and accepted survival which was affected atherosclerotic natural progress axis lines. This is the main difference of our study. A significant correlation was found between group 7 and groups 2, 3 and $4(p=0.000)$. Thus, we thought that the progression rate of atherosclerosis and determination of the efficacy of other treatment methods are the most important factors in survival duration. Groups 3,7 and 6 demonstrated 6-year survival rates of $72.52 \%, 76.14 \%$ and $90.27 \%$ respectively, demonstrating the successful application of complete vascularization in spite of unpreventable atherosclerosis grow up. These findings also emphasize the importance of more accurately reevaluating non-surgical treatment options. Furthermore, the 6-year survival rates were $69.38 \%$. In octogenarian patient with normal angiography findings (group 1), compared with $76.14 \%$ and $90.27 \%$ in groups 7 and 6 respectively; this may be attributable to the low patient numbers in our study. 


\section{Conclusion}

Consequently, our study shows that the interventions such as $\mathrm{PCl}$ and/or medications were not as successful as the surgery in selected octogenarian patients. Patient selection had to take into consideration not only the success of any intervention but also survival duration of patients following coronary artery bypass surgery. Thus after the CAG, the present findings underscore the importance of patient selection for CABG is more preferred in $\mathrm{PCl}$ group.

\section{Declaration of conflict of interest}

The authors received no financial support for the research and/or authorship of this article. There is no conflict of interest

\section{References}

1. Shinmura K. Cardiac Senescence, Heart Failure, and Frailty: A Triangle in Elderly People. Keio J Med 2016; 65: 25-32

2. National Center for Health Statistics. Vital statistics of the United States, 1989: Vital Health Statistics, vol 2, Washington, DC: US Government Printing Office, 1992, 11.

3. National Center for Health Statistics. Current estimates from the National Health Interview Survey, 1989; Vital Health Statistics, series 10. Washington, DC: US Government Printing Office, 1990, No176.

4. Johnson WM, Smith JM, Woods SE, Hendy MP, Hiratzka LF. Cardiac surgery in octogenarians: does age alone influence outcomes? Arch Surg 2005; 140:1089-93. doi:10.1001/archsurg.140.11.1089.

5. Peterson ED, Alexander KP, Malenka DJ et al; American Heart Association Chronic CADWorking Group. Multicenter experience in revascularization of very elderly patients. Am Heart J 2004; 148: 486-92.

6. Dakik HA, Hannoush H, Obeid MY. Coronary artery bypass surgery in octogenarians: outcomes in a tertiary referral university hospital in a developing country. Int J Cardiol 2003; 92: 253-6.

7. Amano A, Yoshida S, Takahashi A, Nagano N, Kohmoto T. Coronary artery bypass grafting in the elderly. Chest 2000; 117: 1262-70.

8. Huber $\mathrm{CH}$, Goeber V, Berdat P, Carrel T, Eckstein F. Benefits of cardiac surgery in octogenarians- postoperative quality of life assessment. Eur J Cardiothorac Surg 2007; 31: 1099-105.

9. Zingone B, Gatti G, Rauber E, Tiziani P, Dreas L, Pappalardo A, Benussi B, Spina A. Early and Late Outcomes of Cardiac Surgery in Octogenarians. Ann Thorac Surg 2009; 87:71-8.

10. Alexander KP, Anstrom KJ, Muhlbaier LH et al. Outcomes of cardiac surgery patients $>$ or $=80$ years: results from the National Cardiovascular Network. J Am Coll Cardiol 2000; 35: 731-8.
11. Dacey LJ, Likosky DS, Ryan TJ et al. for the Northern New England Cardiovascular Disease Study Group, Long term survival after surgery versus percutaneous intervention in Octogenarians with multi vessel disease. Ann Thorac Surg 2007; 84: 1904-11.

12. Craver JM, Puskas JD, Weintraub WW. 601 octogenarians undergoing cardiac surgery: outcome and comparison with younger age groups. Ann Thorac Surg 1999; 67: 1104-10.

13. De Gregorio J, Kobaayashi Y, Albiero R. Coronary stenting in the elderly: short term outcome anf long term angiographic and clinical follow-up. J Am Coll Cardiol 1998; 32: 577-83.

14. Vander Salm TJ, Kip KE, Jones RH. What constitutes optimal surgical revascularization? Answers from the Bypass Angioplasty Revascularization Investigation (BARI). J Am Coll Cardiol 2002; 39: 565-72.

15. Dalrymple-Hay MJ, Alzetni A, Aboel Nazar. Cardiac surgery in the elderly. Eur J Cardiothorac Surg 1999; 15: 61-6.

16. Loop FD, Golding LR, Macmillan JP. Coronary artery surgery in women compared with men: analyses of risks and long term results. J Am Coll Cardiol 1983; 1: 383-90.

17. Eritsland J, Arnesen H, Fjeld NB. Risk factors for graft occlusion after coronary artery bypass grafting. Scand J Thorac Cardiovasc Surg 1995; 29: 63-9.

18. Morris RJ, Strong MD, Grunewald KE. Internal thoracic artery for coronary bypass grafting in octogenarians. Ann Thorac Surg 1996; 62: 16-22.

19. Barner HB. Arterial grafting: techniques and conduits. Ann Thorac Surg 1998; 66: 2-5.

20. Reardon MJ, Conklin LD, Reardon PR. Coronary artery bypass conduits:review of current status. J Cardiovasc Surg 1997; 38: 201-19.

21. Subramanian VA. Less invasive arterial CABG on a beating heart. Ann Thorac Surg 1997; 63: 68-71.

22. Cooper GJ, Underwood MJ, Deverall PB. Arterial and venous conduits for coronary artery bypass: a current review. Eur J Cardiothorac Surg 1996; 10: 129-40.

23. Mack MJ, Osborne JA, Shennib H. Arterial graft patency in coronary bypass grafting: what do we really know? Ann Thorac Surg 1998; 66: 1055-9.

24. Williams DB, Carillo RG, Traad EA. Determinants of operative mortality in octogenarians undergoing coronary bypass. Ann Thorac Surg 1995; 60: 1038-43.

25. Brener SJ, Lytle BW, Casserly IP, Schneider JP, Topol EJ, Lauer MS. Propensity analyses of long term survival after surgical or percutaneous revascularization in patients with multi vessel coronary artery disease and high risk features. Circulation 2004; 109: 2209-5. 